\title{
PENGURUSAN STRES MELALUI PENDEKATAN ISTIGHATHAH
}

\author{
Nur Adilah Adilah Omar dan Wan Nasyrudin Wan Abdullah \\ Fakulti Pengkajian Islam Universiti Kebangsaan Malaysia \\ nuradilah_omarpink@yahoo.com
}

Diterima 11 Januari 2018 | Direview 23 Agustus 2018|Diterbitkan 31 Desember 2018

\begin{abstract}
:
Every individual will not escape stress, and each individual face different stress situations because stress is closely related to lifestyles. From a religious perspective, stress is a test from God to mankind. Therefore, religion plays an important role in addressing various issues and questions of human life, especially those related to stress problems. There are various approaches in religion that can be used to treat stress disorders, including the approach of faith, worship and morals. This study identified the stress management with the approach of worship i.e Istighathah worship. The method used in this study is qualitative research method which based on literature reviews from books, journals, theses, al-Quran and hadiths that serve as informational analysis purposes. The findings suggest that the methods may be used to treat stress with Istighathah approach is to perform diiker, prayers, reading al-Quran and istighfar. These methods are expected to be able to provide calm and peace of mind.
\end{abstract}

Keywords: Stress Management, way, istighathah

\begin{abstract}
Abstrak:
Setiap individu tidak akan terlepas daripada mengalami stres, dan setiap individu itu menghadapi situasi stres yang berbeza kerana ianya berkait rapat dengan gaya bidup masing-masing. Dari perspektif agama stres adalah bentuk. ujian dari Allab terhadap hambaNya. Oleh sebab itu agama memainkan peranan penting dalam menangani pelbagai permasalahan dan persoalan hidup manusia terutamanya yang berkaitan dengan masalah stres. Ini kerana agama berkait rapat dengan kesihatan mental dan emosi. Terdapat pelbagai pendekatan dalam agama yang boleh digunakan bagi merawat penyakit stres, antaranya ialah dengan pendekatan iman, ibadah dan akblak. Oleh yang demikian kajian ini dijalankan adalah untuk mengenal pasti pengurusan stres dengan pendekatan ibadah iaitu ibadah Istighathah. Metode yang digunakan dalam kajian ini ialah kaedah penyelidikan kualitatif berdasarkan kajian lepas dan analisis sumber primer seperti buku, jurnal, tesis, al -Quran dan hadis
\end{abstract}




\begin{abstract}
digunakan bagi tujuan analisis maklumat. Hasil kajian mendapati pendekatan yang boleh digunakan untuk merawat stres dengan pendekatan Istighathah ialah dengan melaksanakan zikir, doa, solat, baca al-Quran dan istighfar, ianya mampu memberi ketenangan dan ketenteraman hati. Diharapkan pendekatan tersebut sesuai di gunakan oleh masyarakat Islam dalam merawat stres.
\end{abstract}

Kata kunci: Pengurusan Stres, pendekatan, ibadah Istighathah

\title{
Pendahuluan
}

Stres merupakan sebahagian daripada masalah dalam kehidupan kebanyakkan orang pada masa kini. Manusia tidak dapat lari daripada merasai pengalaman stres, dan setiap individu berbeza keadaannya kerana ianya bergantung kepada pengalaman yang dimiiki oleh masing-masing. Setiap individu pasti akan mengalami kegagalan atau kekecewaan dalam hidup, berpuncak dari keadaan tersebut menyebabkan diri individu tersebut mengalami perasaan sedih, gelisah, ragu-ragu, dan lain- lain lagi. Ciri- ciri tersebut adalah petanda seseorang itu mengalami stres. Sekiranya seseorang itu memandang stres sebagai suatu sudut yang positif maka ianya akan menghasilkan sifat yang baik, contohnya berani menyahut cabaran, tabah menghadapi kesusahan dan sabar mengharungi ujian. Sebaliknya jika seseorang itu memandang stres sebagai suatu yang negatif maka hasilnya ia menjadi perkara yang menyusahkan, dan jika tidak diatasi dengan baik akan terjadinya masalah kekecewaan, kesedihan, lemah semangat, rasa terganggu, berfikiran singkat dan seumpamanya.

Perkataan "stress" boleh membawa makna yang berbeza bagi setiap individu dan situasi. Dalam istilah fizik ianya bermaksud regangan atau tekanan. Stres boleh dilihat dari konteks sel tubuh dan juga dari konteks kesihatan jiwa. Dalam konteks sel tubuh, apabila proses perubahan tekanan dari luar belaku ianya menyebabkan tindak balas kimia berlaku di dalam tubuh badan manusia. Adapun dari konteks kesihatan jiwa, stres merujuk kepada manifestasi sistem minda-tubuh yang boleh diramal akibat daripada tekanan dalam dan luaran, jika berterusan boleh memudaratkan diri dan penyakit. ${ }^{1}$

Stres juga boleh didefinisikan sebagai satu keadaan yang tidak seimbang di dalam aspek intelektual, emosional dan fizikal individu dan stres dan stres

1 Hatta Sidi, Menjaga Kesihatan Jiwa: Teknik Mengurus Stres (Bentong: PTS Publications \& Distributor Sdn. Bhd, 2003). 
dijanakan oleh pandangan individu terhadap sesuatu keadaan yang mengakibatkan tindak balas fizika dan emosional ini. ${ }^{2}$

Ahli psikologi Islam seperti al-Ghazali, al- Razi, Muhammad 'Uthman Najati, Muhammad 'Izudin Taufiq, Samih 'Atif al-Zin, dan Hassan Langhulung melihat tekanan dari segi kelisahan jiwa, contohnya gelisah, kecewa, bimbang yang keterlaluan dan takut. Emosi tersebut muncul kerana hati manusia tidak beriman kepada Allah SWT. Selain itu juga, tekanan dapat dikaitkan dengan penyakit hati seperti hasad, dengki, sombong, riak dan ujub. Abu Bakar al- Razi mendefinisikan tekanan sebagai satu gangguan fikiran yang berpunca daripada seseorang itu kehilangan sesuatu yang dicintai. ${ }^{3}$

Dengan munculnya semua pelbagai keadaan seperti di atas menyebabkan seseorang individu menjadi putus asa, keresahan dalam diri, dan ini menyebabkan segala aktiviti harian yang berkaitan dalam hidup tidak dapat dilakukan dengan tenang dan ianya menyebabkan stres berlaku. Keadaan seperti ini tidak dapat diatasi oleh setiap individu, ianya memerlukan kaedah yang tertentu untuk mengawal keadaan yang berpuncak daripada perasaan tersebut. Islam telah menggariskan cara-cara untuk merawat masalah stres.

Pengetahuan terhadap ilmu agama amat penting untuk menyelesaikan masalah tersebut dan mencapai kepada kehidupan yang baik dan juga kebahagian di dunia dan akhirat. Allah Swt adalah tempat mengadu yang paling tepat di setiap peramasalahan hidup yang dihadapi oleh manusia, mengadu dengan bermohon pertolongan kepada Allah Swt. Allah Swt. telah mengutuskan Nabi Saw. kepada hambanya untuk menyampaikan risalah dan menyeru manusia agar sentiasa dekat dengan-Nya.

Sebagai manusia yang beriman kita digalakan untuk senantiasa mendekatkan diri kepada Allah Swt, dengan melaksanakan segala ibadah dan amalan seperti mana yang dilakukan oleh Nabi Saw. Dengan ibadah yang di lakukan dapat menghasilkan ketenangan hati dan ketenteraman jiwa. Oleh yang demikian masalah stres dapat diatasi. Terdapat banyak pendekatan dalam Islam yang boleh digunakan bagi merawat stres salah satunya ialah istighatsah, ini dapat dibuktikan dengan kajian Aini Zakiyatul Fuadah berkenaan peranan Istighathah dalam mengurangi tekanan (kecemasan) para siswa Indonesia ketika menghadapi peperiksaan peringkat Kebangsaan (Ujian Nasional UN), ternyata

\footnotetext{
2 Yvonne Gold and Robert A. Roth, Teachers Managing Stress \& Preventing Burnout (New York: Routledge, 2013).

3 Muḥammad 'Uthmān Najātī, Jiwa dalam Pandangan Para Filosof Muslim (Bandung: Pustaka Hidayah, 2002).
} 
dengan mengunakan pendekatan amalan istighathah telah menghadirkan kecerdasan dan kekuatan spiritual pada diri siswa terlibat. Hal ini dapat dibuktikan dengan adanya perubahan-perubahan yang terjadi pada diri siswa pada saat setelah mengikuti pelaksaan kegiatan istighathah. Pada raut wajah mereka nampak lebih tenang, rileks, dan penuh rasa percaya diri. ${ }^{4}$

Istighathah adalah salah satu bentuk ibadah yang dilakukan oleh kaum muslimin sewaktu menghadapi kesulitan, serta dengan istighathah seseorang itu boleh mencapai ketenangan hati dan jiwa. Ini bersesuaian dengan peristiwa Nabi Muhammad SAW memohon bantuan dari Allah Swt, saat itu beliau berada di tengah berkecamuknya perang badar dimana kekuatan musuh tiga kali lipat lebih besar dari pasukan Islam. Kemudian Allah mengabulkan permohonan Nabi SAW dengan memberi bantuan pasukan tambahan berupa seribu pasukan malaikat.

Selain itu juga istighathah boleh dimaksudkan sebagai memohon pertolongan dari Allah Swt. untuk mewujudkan sesuatu keajaiban, ataupun sesuatu yang paling baik dan perkara tersebut tidak dianggap sebagai perkara mudah untuk mewujudkannya. Istighathah pada dasarnya sama dengan berdoa,akan tetapi pada konotasinya lebih dari sekadar berdoa, ini kerana biasanya istighathah dimulakan dengan wirid-wirid tertentu, terutamanya istighfar, sehingga Allah berkenan dan mengabulkan doa tersebut. Pada umumnya istighathah adalah meminta pertolongan ketika manusia menghadapi sesuatu kesukaran atau permasalahan samada yang berkaitan dengan jiwa dan hati dalam hidup.

Pensyariatan istighathah adalah bukan perkara baru kerana terdapat dalildalil padanya di dalam nas-nas syaria'ah atau teks-teks al-Quran atau hadis Nabi SAW. Dan ia juga dinyatakan dalam surah al-Anfal ayat (8:9):

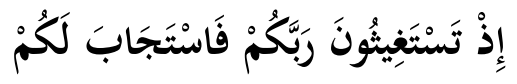

"(Ingatlah wahai Mubammad), ketika kamu memohon pertolongan kepada Tuhanmu lalu Dia mengabulkan permobonanmu."

Ayat ini menjelaskan peristiwa ketika Nabi Muhammad SAW memohon bantuan dari Allah Swt. saat itu beliau berada di tengah berkecamuknya perang badar dimana kekuatan musuh tiga kali lipat lebih besar

\footnotetext{
4 Ainani Zakiyatul Fuadah, "Peran Istighasah dalam Mengurangi Kecemasan Siswa Menghadapi Ujian Nasional Di UPTD SMAN I Mojo Kediri: Kajian Fenomenologis Psikosufistik Pendidikan Islam," Didaktika Religia 2, no. 2 (2014).
} 
dari pasukan Islam. Kemudian Allah mengabulkan permohonan Nabi dengan memberi bantuan pasukan tambahan berupa seribu pasukan malaikat.

Pelbagai kaedah yang boleh digunakan untuk merawat gejala stres antaranya ialah kaedah Islam yang boleh memberi kesan kepada kesihatan jiwa dan ketenteraman hati. Mereka yang mengalami masalah stres khususnya di kalangan para guru seharusnya berusaha mencapai solat yang khusyuk, senantiasa berzikir dan menghayati isi kandungan al-Quran. Amalan-amalan tersebut terbukti mampu menjadikan diri kita sihat secara zahir dan batin. Amalan-amalan tersebut adalah sebahagian daripada amalan istighatsah di mana ianya mampu mendekatkan diri kita kepada Allah. Namun demikian ramai yang tidak memahami dan mengaplikasikan amalan Istighathah tersebut dalam diri mereka. Kajian ini akan dijalankan untuk mengetahui pengurusan stres menggunakan amalan istighatsah dalam menangani masalah stres.

\section{Metodologi Kajian}

Kajian ini menggunakan analisis sumber ilmiah yang mengkaji pengurusan stres dengan menggunakan ibadah istighathah. Sumber rujukan utama dalam kajian ini melibatkan al-Quran dan hadith-hadith sahih dalam memperkukuhkan sorotan kajian. Kajian literatur juga turut menggunakan sumber-sumber rujukan seperti kertas kerja penyelidikan, tesis, buku, jurnal dan prosiding sebagai panduan.

\section{Konsep Istighathah}

Al-Istighathah (الإستغاثة), maksud dari perkataan ini ialah meminta disampaikan permohonan melalui seseorang kepada Allah SWT bagi menunaikan hajatnya. Manakala dalam kajian lain menjelaskan bahawa kata tastagbitsuna(تستغيثون) berasal dari kata istaghatsa-yastaghistsu-istighatsatan, maksudnya menjerit "wa ghauts" (tolong!). Perkataan ini diambil dari kata ghouts, atau ghawats atau ghuwats, yang membawa maksud pertolongan. Kabilah dalam Bahasa arab juga disebut dengan perkataan ghouts, kerana para ahli kabilah saling tolong-menolong di antara sesama mereka. Perkataan ini juga memiliki asal yang bermaksud air hujan. Jadi perkataan istighatsah dengan asal ghaits ini berarti memohon hujan kepada Allah, seperti yang terdapat dalam surah alKhaf ayat 29. Yang bermaksud memohon pertolongan dan berdoa kepada Allah.

Para ulama ahli hadis telah menerangkan secara jelas makna istighatsah menurut istilah syari'ah, sebagaimana dinyatakan oleh Syeikh Muhammad bin 
Shalih Al-'Utsaimain rahimahullah bahawa istighatsah itu bermaksud meminta bantuan, iaitu agar terlepas dari kesulitan dan selamat dari kebinasaan. ${ }^{5}$

Kata istighatsah ini mempunyai berbagai makna dari berbagai pendapat diantaranya: Istighatsah berasal dari perkataan: "ghoutsu, ghotsa, ghoutsan, istighotsan" yang membawa maksud pertolongan, menolongnya, membantunya. ${ }^{6}$

Menurut Muhamad Ibn Abdul Wahab dalam "kitab tauhid", istighatsah adalah meminta sesuatu untuk menghilangkan kesusahan atau kesedihan, dengan hanya memohon bantuan kepada Allah SWT. Perkara tersebut dibenarkan apabila termasuk dalam segala urusan yang berbentuk kebaikan.

Istighatsah pada asalnya sama macam berdoa akan tetapi bila disebut kata istighatsah konotasinya lebih dari sekadar berdoa, kerana yang memohon bantuan dan pertolongan di dalam istighatsah adalah bukan hal yang biasa sahaja. Oleh kerana itu, istighatsah sering dilakukan secara kolektif dan biasanya dimulai dengan wirid-wirid tertentu, terutamanya istighfar, sehingga Allah Swt berkenan untuk mengabulkan permohonan itu..

Terdapat hadis Nabi yang membicarakan tentang istighatsah antaranya:

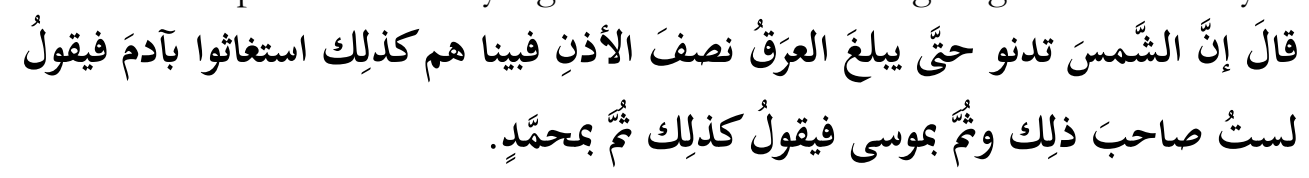

"Matahari akan mendekat ke kepala manusia di hari kiamat sehingga keringat sebahagian orang keluar hingga mencapai separuh telinganya, ketika mereka berada pada keadaan seperti itu mereka beristighatsah ( memohon pertolongan) kepada Nabi Adam, kemudian kepada Nabi Musa kemudia kepada Nabi Mubamad SAW." (H.R. alBukhari)

Di dalam al-Qur'an juga terdapat ayat yang menyebut tentang istighatsah, berdasarkan firman Allah Swt QS. Al- Anfaal: 9

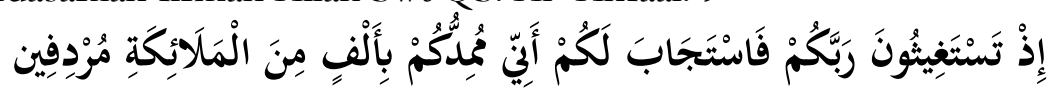

\footnotetext{
${ }^{5}$ Khoirul Muhaimin, "Implementasi Terapi Istighatsah dalam Mengatasi Kenakalan Peserta Didik Kelas IX Di SMP YPM 3 Beringin Taman Sidoarjo Tahun Pelajaran 2013-2014" (Skripsi, UIN Sunan Ampel Surabaya, 2014), http://digilib.uinsby.ac.id/123/.

6 Mubaroq Dafid, "Pengaruh Istighosah Terhadap Percaya Diri Siswa Menghadapi Ujian Nasional Di Madrasah Tsanawiyah Negeri Karangrejo” (Skripsi, IAIN Tulungagung, 2014), http://repo.iain-tulungagung.ac.id/.
} 
"(Ingatlah) ketika kamu memohon pertolongan kepada Tuhan kamu, lalu ia perkenankan permobonan kamu (dengan firmanNya): "Sesunggubnya Aku akan membantu kamu Dengan seribu (bala tentera) dari malaikat Yang datang berturut-turut."

Ayat tersebut menjelaskan bahawa dalam setiap urusan atau masalah, manusia haruslah senantiasa ingat kepada Allah baik dengan melakukan ibadah shalat ataupun berdo'a, ini kerana Allah akan membantu hambanya dengan mengabulkan semua do'a hambanya yang bersungguh dalam berdo'a. Hanya kepada Allah tempat kita memohon pertolongan dan bantuan, ini kerana Allah yang maha mendengar dan maha mengabulkan do'a.

Istighatsah merupakan himpunan doa-doa, ianya juga dibaca untuk menghubungkan diri kepada Allah yang mengandungi kehendak dan permohonan kepada-Nya. Didalamnya terdapat permohonan bantuan tokohtokoh popular dalam amal soleh.

Berdasarkan dalam kitab Al-Istighatsu Fir Raddi a'al Bakri, menyatakan istighatsah terbahagi kepada dua jenis iaitu:

1. Istighathah masyru'ah iaitu Istighathah yang disyariatkan dalam agama Islam. Di dalam bahagian ini terdapat bentuk yang tertentu antaranya ialah

a. Istighathah kepada Allah Swt., perkara ini yang disyariatkan dan diperintahkan dalam Islam. Tidak ada orang lain yang dapat menghilangkan kesusahan dan keresahan dalam hati secara mutlak melainkan Allah Swt., dan setiap pertolongan yang hadir dalam hidup manusia adalah semuanya dari Allah Swt. Ini berdasarkan firman Allah Swt. tentang istighathah yang dilakukan oleh Nabi Saw. dan para sahabat pada waktu malam sebelum peperangan Badar

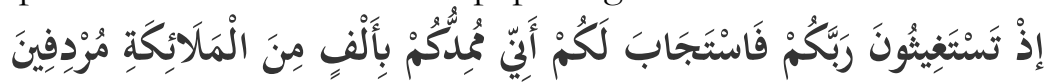

"(Ingatlah), ketika kamu memohon pertolongan kepada Tuhanmu, lalu diperkenankan-Nya bagimu: "Sesunggubnya Aku akan mendatangkan bala bantuan kepada kamu dengan seribu malaikat yang datang berturut-turut." (QS. Al-Anfaal: 9)

Allah memerintahkan kepada setiap hambaNya untuk berdoa dan beristighathah kepadaNya, dengan maksud lain Allah sentiasa ada menolong hambanNya dalam keadaan susah, sebagaimana firman Allah SWT.

\footnotetext{
${ }^{7}$ Ibn Taimiyah, Istighatsu Fir Raddi 'alal Bakri, 1st ed. (Dar al-Riyadh, 1998).
} 

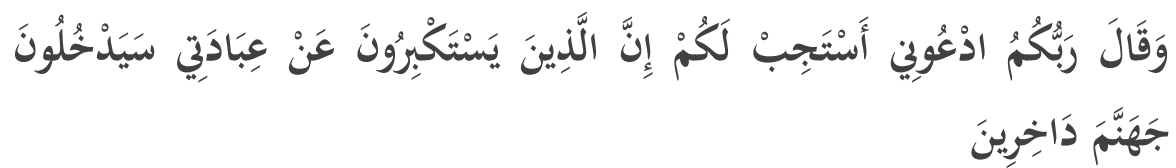

'Dan Tuban kamu berfirman: Berdoalab kamu kepadaKu nescaya Aku perkenankan doa permohonan kamu. Sesunggubnya orang-orang yang sombong takbur daripada beribadat dan berdoa kepadaKu, akan masuk neraka Jahannam dalam keadaan bina." (QS. Al-Ghafir: 60)

Adapun maksud perkataan "beribadat " dalam ayat ini ialah "berdoa". Maksudnya jika seseorang ditimpa kesusahan Allah memerintahkan kepada hambanNya untuk berdoa.

b. Istighathah kepada Nabi Saw., dan juga kepada masyarakat mukmin. Ianya melibatkan perkara-perkara yang hanya mampu dilakukan oleh manusia secara umum. Istighathah sejenis ini dibolehkan, sepertimana yang kita meminta pertolongan kepada orang yang mampu melakukan hal tersebut. Terdapat dalil yang menunjukan Istighatsah terhadap Nabi Saw., sebagaimana firman Allah SWT kepada Nabi Musa alaihi salam.

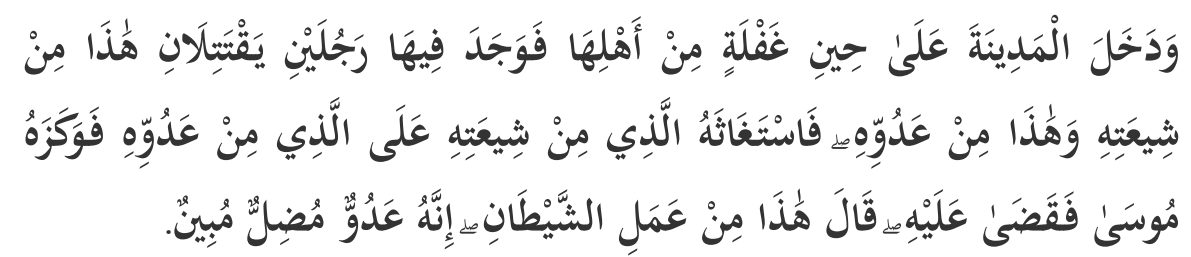

"Dan Musa masuk ke kota (Memphis) ketika penduduknya sedang lengah, maka didapatinya di dalam kota itu dua orang laki-laki yang berkelabi; yang seorang dari golongannya (Bani Israil) dan seorang (lagi) dari musubnya (kaum Fir'aun). Maka orang yang dari golongannya meminta pertolongan kepadanya, untuk mengalabkean orang yang dari musubnya lalu Musa meninjunya, dan matilah musubnya itu. Musa berkata: "Ini adalab perbuatan syaitan sesunggubnya syaitan itu adalah musub yang menyesatkan lagi nyata (permusubannya)."(QS. Al-Qassas: 15)

Dalam ayat ini, orang dari kalangan Bani Israel beristighathah meminta pertolongan kepada Nabi Musa alaihis salam dalam perkara yang 
mampu dilakukan oleh Nabi Musa, dan hal ini tidak bertentangan dengan kesempurnaan tauhid.

Apabila seseorang menghadapi kesulitan atau masalah, tidak ditegah baginya untuk meminta tolong kepada seseorang yang mampu melakukannya, akan tetapi dalam rangka menjaga kesempurnaan tauhid, kita wajib meyakini bahawa pertolongan tersebut berdasarkan sebab semata-mata, dan menjauhi dari memiliki pengaruh bahawa pertolongan tersebut secara langsung dapat menghilangkan kesulitan yang kita alami. Ini kerana kita harus meyakini bahawa setiap sesuatu berlaku itu datangnya dari Allah Swt., dan Allah jualah yang mampu menghilangkan semua kesulitan yang dihadapi. Elakkan daripada bersandar penuh kepada orang yang mampu melakukan pertolongan tersebut dan seterusnya lalai dalam mengingati dan mendekati Allah SWT. Hal tersebut akan merosakkan kesempurnaan tauhid dalam diri.

2. Istighathah mamnu'ah iaitu Istighathah yang dilarang atau diharamkan dalam agama Islam. bentuk Istighathah ini terbahagi kepada dua:

a. Istighathah kepada orang yang masih hidup atau orang yang sudah mati dan ianya tidak wujud di hadapan kita. Maksudnya beristighathah kepada orang yang tidak mampu melakukan hal-hal yang tertentu melainkan Allah SWT, contohnya memberi rezeki, keselamatan, menyembuhkan penyakit, menolak bencana, mengampunkan dosa, memberi hidayah dan sebagainya. Semua perkara tersebut adalah di bawah kekuasaan Allah SWT. Tiada siapa yang mampu melakukanya melainkan Allah. Sekiranya seseorang itu beristighathah kepada orang yang ada kuasa di luar kemampuannya maka ianya di kira bertentangan dengan ajaran agama, dan boleh diketogerikan sebagai perbuatan syirik besar yang boleh menyebabkan orang yang melakukan perkara tersebut murtad dengan katalain keluar dari agama Islam

\section{Bentuk Amalan Istighathah}

Menurut kajian lepas yang dibuat oleh Umi Wakhdatul Mubarok dalam thesisnya menyatakan bahawa Istighatsah adalah melaksanakan ibadah dan melafazkan bacaan-bacaan yang mengandungi doa, zikir, selawat yang bermanfaat untuk memohon pertolongan kepada Allah Swt. ${ }^{8}$

8 Umi Wakhidatul Mubarok, "Pengaruh Keaktifan dalam Mengikuti Pengajian Istighosah Malam Senin terhadap Implementasi Sikap Sabar” (Skripsi, STAIN Salatiga, 2011). 


\section{Doa}

Doa berasal dari bahasa arab yang asal katanya dari kalimah: يدعو الدعاء yang bermaksud panggilan, mengundang, permintaan, permohonan, doa dan sebagainya. Berdoa maksudnya menyeru, memanggil atau memohon pertolongan kepada Allah SWt atas segala sesuatu yang diinginkan. Seruan kepada Allah SWT itu boleh di lakukan dalam bentuk ucapan tasbih (Subhanallah), pujian (Alhamdulillah), istighfar. ${ }^{9}$

Di dalam Al-Quran dan hadis telah disebutkan bahawa Allah menyuruh hambaNya berdoa kepadanya secara langsung kepadaNya tanpa perantaraan, dan Allah akan mengabulkan segala permintaan yang dipohon oleh hambaNya kepadaNya. Ini berdasarkan firman Allah SWT:

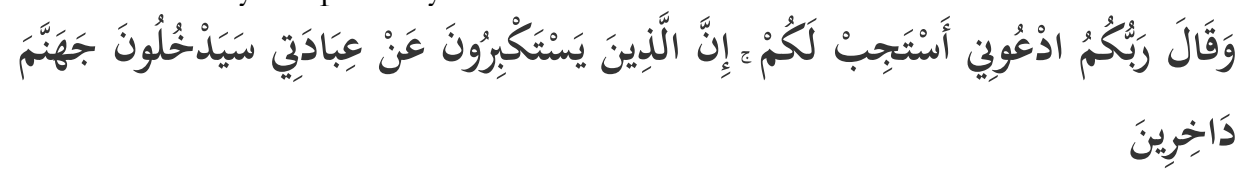

"Dan Tuhanmu berfirman: "Berdoalah kepada-Ku, niscaya akan Kuperkenankan bagimu. Sesunggubnya orang-orang yang menyombongkan diri dari menyembah-Ku akan masuk neraka Jahannam dalam keadaan bina dina." (QS. al-Mu'minun: 60)

Allah SW'T memerintahkan kepada hambaNya agar berdoa di saat menghadapi tekanan atau kesuliatan, dan Allah berjanji untuk mengabulkannya. Maha suci Allah yang maha agung yang melimpahkan kurniaan dan anugerah yang tidak terhingga kepada hambaNya, akan tetapi apabila ada hambaNya yang menyombongkan diri dan tidak mengingati Allah maka, Allah akan membalasnya dengan azab dan akan dimasukkan ke dalam neraka jahanam.

Selain itu juga, doa boleh di ertikan sebagai satu kegiatan yang menggunakan kata-kata baik secara terbuka bersama-sama ayau secara peribadi untuk mengajukan tuntutan-tuntuan kepada Allah SWT. Ibnu Arabi memandang doa sebagai satu bentuk komunikasi dengan Allah yang mempunyai keupayaan untuk membersihkan dan menghilangkan nilai-nilai kesyirikan dalam diri. ${ }^{10}$

\footnotetext{
${ }^{9}$ Mubarok, 7.

${ }^{10}$ Wiji Dwi Agustin, "Pengaruh Doa terhadap Coping Stress pada Santri di Pondok Pesantren Sunan Pandanaran Ngunut" (Skripsi, IAIN Tulungagung, 2014), http://repo.iaintulungagung.ac.id.
} 


\section{Zikir}

Berzikir adalah salah satu amalan yang disyariatkan dan sangat dituntut dalam Islam. Ianya boleh dilakukan dengan hati ataupun lisan, sebaik-baiknya dengan kedua-duanya sekali. Sekiranya ingin melakukan zikir hanya dengan hati (zikir Khofi), dengan cara berdiam diri, hati dan fikiran sentiasa mengingati Allah. Adapun zikir dengan lisan (zikir jahri), lisannya mengucap kalimah-kalimah tertentu.

Zikir merupakan bukti keterikatan seorang hamba kepada penciptanya. Seharusnya seorang yang bergelar muslim sentiasa membasahi lidah mereka dengan zikir- zikir yang ma'tsur, iaitu zikir-zikir yang diambil daripada Al-Quran dan sunnah, seperti zikir selepas solat, zikir pada waktu pagi dan petang serta zikir-zikir yang dibaca berkaitan dengan peristiwa atau sebab yang tertentu.

Setiap muslim sudah mengetahui bahawa zikir itu sesuatu yang penting dan sangat besar manfaatnya kepada diri muslim itu sendiri. Melakukan zikir merupakan satu amalan yang mulia dan paling efektif, kerana ianya mampu mendekaktkan diri kita kepada Allah SWT'. Sesungguhnya Allah telah memerintahkan untuk berzikir dalam beberapa ayat Al-Quran, ini berdasarkan firman Allah SWT:

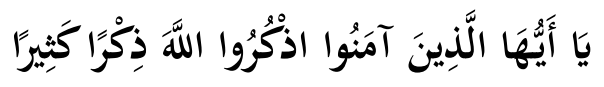

"Wahai orang-orang yang beriman, beriikirlah (menyebut nama ALLAH) dengan zikir yang sebanyak-banyaknya.”(QS. al-Ahzab: 41)

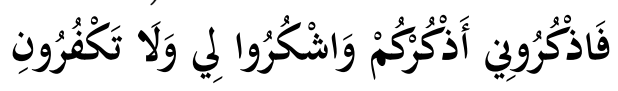

"Oleh itu ingatlah kamu kepada-KU (dengan mematubi syariatKu), supaya aku membalas kamu dengan kebaikan, dan bersyukurlah kamu kepada-KU dan janganlah kamu kufur (akan nikmat-Ku)." (QS. al-Baqarah: 152)

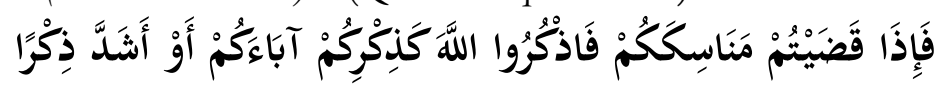

"Apabila kamu telah menyelesaikan ibadah haji kamu, maka hendaklab kam menyebut-nyebut dan mengingati Allah ( dengan membesarkanNya) sebagaimana dabuu menyebut-nyebut(memuji-muji) nenek moyang kamu, babkan dengan sebutan yang lebih baik lagi." (QS. al-Baqarah: 200)

Terdapat banyak lagi ayat-ayat al-Quran lain yang menjelaskan tentang zikir. Dalam ayat-ayat di Allah SW'T mengeluarkan perintah agar perbanyakkan zikir kepadaNya. Seseorang yang kurang berzikir kepada 
Allah akan mendapat kerugian. Kerugian yang harus di tanggung tersebut lebih besar daripada keuntungan di dunia yang mereka dapat ketika mereka lalai kepada Allah ${ }^{11}$

Terdapat riwayat Nabi SAW sebagaimana dalam kitab Al-Baihaqi dalam kitabnya Syucbul Al-Iman No. 508 dan Abu Nucaim dalam kitabnya Al-Hilyah Jilid 5/362, dari hadis Ummul Mukminin Aisyah RA, bahawa sesungguhnya Nabi SAW bersabda:

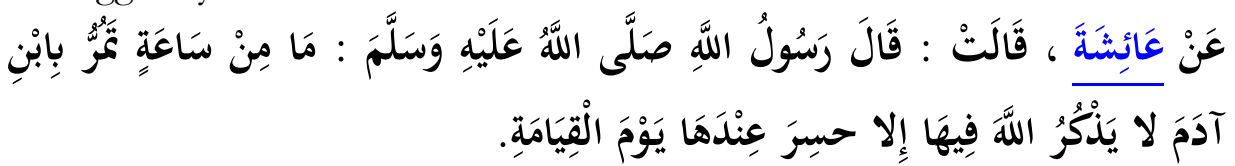

"Setiap saat yang dilewatkan oelh seseorang anak cucu Adam tanpa berzikir mengingati Allah Ta'ala, adalah kerugian yang akan ia tanggung pada khiamat nanti"

Maka berzikir mengingati Allah mempunyai pengaruh yang besar dalam mencapai sesuatu hal-hal yang dicari, hal ini kerana keistimewaanya, serta ganjaran dan pahala yang diharapkan oleh seorang hamba.

Unsur utama di dalam zikir ialah Allah SW'T. Allah adalah awal dan akhir segala zikir manusia. Orang yang berzikir melalui lisannya akan tetapi tanpa penghayatan dalam fikiran serta lubuk hati yang paling dalam, sudah asti tidak akan memperolehi kekuatan kecuali sedikit. Tetapi bagi mereka yang berzikir dengan lisan, kemudian meyakini di dalam hatinya, serta fikiran turut menghayatinya maka mereka itulah yang mampu mendekatkan diri kepada Allah SWT.

\section{Selawat}

Selawat merupakan suatu bentuk jama dari kata salla atau salat yang bermaksud doa, keberkatan, kemuliaan, kesejahteraan dan ibadah. Jadi shalawat menurut bahasa dimaksudkan sebagai do'a. Firman Allah berbunyi

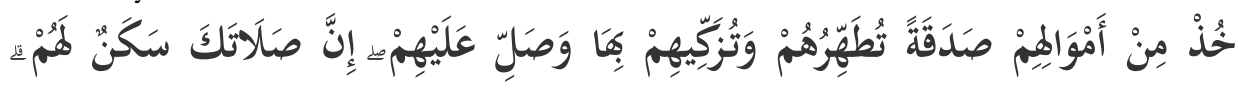

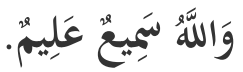

11 Abdurrazak bin Abdul Muhsin al-Badr, Fiqh Doa Dan Zikir, 1st ed. (Pustaka Darul Ilmi, 1999). 
"Ambillah zakat dari sebagian harta mereka, dengan zakat itu kamu membersibkan dan mensucikan mereka dan mendoalah untuk mereka. Sesunggubnya doa kamu itu (menjadi) ketenteraman jiwa bagi mereka. Dan Allah Maha Mendengar lagi Maha Mengetahui."(QS. al-Taubah: 103 )

\section{Praktik Istighathah dalam Perbincangan}

Pelaksanaan Istighathah bertujuan untuk mewujudkan perilaku keagamaan untuk mengingati Allah dalam mencari kebahagian di dunia dan di akhirat. Dan ianya juga sebagai salah satu amalan taqarrub kepada Allah. Dengan pelaksanaan Istighathah yang baik mampu melahirkan ketenangan dan ketenteraman jiwa. Manakala stres juga mampu di atasi dengan pelaksanaan Istighathah seperti berzikir, bertaubat, berdoa, dan memohon ampun di atas semua dosa yang dilakukan disamping berharap agar Allah memberikan kemudahan dan kesejahteraan dalam hidup. ${ }^{12}$

Oleh sebab demikian konsep stres harus difahami oleh setiap individu dalam langkah untuk mengurus stres secara baik dan betul. Setiap individu yang normal akan menggunakan pelbagai kaedah dalam mengurus masalah stres dan menghindarkan diri daripada kesukaran hidup. Akibat dari stres boleh menyebabkan kewujudan penyakit psikiatri danpenyakit fizikal yang berpuncak daripada stres seperti kencing manis, dan tekanan darah tinggi.

Dengan demikian stres haruslah dirawat dengan menggunakan pendekatan yang adil iaitu menerusi rawatan yang bersepadu. Rawatan tersebut adalah (farmakoterapi) ubatan, (psikoterapi) kejiwaan, pendekatan sosial (kemasyarakatan dan terapi spritual (kerohanian). ${ }^{13}$

Jika stres tidak diatasi boleh membawa kepada masalah kesihatan dan penurunan aktiviti harian. Dan juga memberi kesan kepada fisiologi, psikologi, dan tingkahlaku. Antara kesan fisiologi ialah menghadapi penyakit kronik seperti lemah jantung, buah pinggan, dan darah tinggi. Manakala kesan psikologi pula ialah mudah muntah, hilang semangat motivasi dan sebagainya.

\footnotetext{
12 Nikmatul Maula, "Dzikir Istighasah Sebagai Metode Dakwah Pada Jamaah Pengajian Di Pondok Pesantren Al-Fadllu Wal-Fadlilah Kaliwungu Kendal” (Skripsi, UIN Walisongo, 2015), http://eprints.walisongo.ac.id/4800/.

${ }^{13}$ Mohamed Hatta Shaharom, Etika Perubatan Islam dan Isu-isu Psikiatri (Kuala Lumpur: Dewan Bahasa dan Pustaka, 2008).
} 
Kesan tingkah laku pula adalah seseorang individu itu akan mudah merasa marah dan tidak melakukan kerja dengan sempurna. ${ }^{14}$

Seperti yang dinyatakan sebelum ini bentuk amalan Istighathah terdiri daripada doa, zikir, solat, selawat, tahlil, tasbih dan tahmid semua amalan tersebut memberi manfaaat kepada orang yang melaksanakan Istighathah terutamanya bagi seseorang yang menghadapi tekanan atau pun stres. Menurut (Susatyo Yuwono) doa dan zikir menjadi sumber kekuatan bagi seseorang yang berusaha untuk menghindari stres. Harapan yang tinggi disandarkan kepada Allah SWT apabila menghadapi sesuatu ancaman. Sandaran kepada Allah SWT itu melalui doa dan zikir. Melalui zikir perasaan menjadi lebih tenang dan khusuk. Kesan daripada perasaan tersebut seseorang itu mampu berfikir secara positif dan emosi menjadi lebih tenang. Kemarahan dan kesedihan ataupun kegembiraan yang berlebihan akan dapat diatasi dengan baik. ${ }^{15}$

Adapun solat individu mampu merasakan kehadiran Allah jika dilaksanakan dengan baik dan khusyuk. Segala kepenatan fizikal, masalah bebanan fikiran dan emosi yang tinggi kita tinggal ketika menunaikan solat. Dengan demikian solat itu mejadi penawar bagi kekuatan yang muncul dari perasaan stres yang dihadapi. Selain itu juga solat secara teratur dan khusyuk akan mendekatkan individu kepada penciptanya. Hal ini akan menjadi jambatan hubungan Allah SWT dengan individu sehingga Allah tidak akan membiarkan individu tersebut bersendirian. Kesimpulannya Istighathah berkait rapat dengan ibadah yang dapat merawat penyakit stres seperti yang di sebut di atas. Jika ibadah Istighathah di aplikasikan dengan kedah yang baik dan betul ianya mendatangkan hasil yang baik terhadap individu yang mengalami stres.

\section{Pengurusan Stres Dengan Istighatsah}

Berdasarkan kepada teori, model kajian dan kajian-kajian lepas stres merupakan satu fenomena yang lazim dalam sesuatu organisasi dan ianya perlu ditangani dengan baik. Stres adakalanya mendatangkan kesan positif dan juga negatif. Kesan positif yang dapat diperolehi dari stres seperti

\footnotetext{
${ }^{14}$ Cary L. Cooper and Judi Marshall, "Occupational Sources of Stress: A Review of the Literature Relating to Coronary Heart Disease and Mental Ill Health," Journal of Occupational Psychology 49, no. 1 (1976): 11-28, https://doi.org/10.1111/j.2044-8325.1976.tb00325.x. 15 Susatyo Yuwono, "MENGELOLA STRES DALAM PERSPEKTIF ISLAM DAN PSIKOLOGI," Psycho Idea 8, no. 2 (July 1, 2010), https://doi.org/10.30595/psychoidea.v8i2.231.
} 
peperiksaanmenyebabkan seseorang membuat persiapan rapi untuk menghadapinya. ${ }^{16}$

Setiap individu yang menghadapi masalah pasti akan mencari jalan untuk mengatasi masalah tersebut. Individu normal akan menggunakan pelbagai cara untuk menghindari stres dan mengelakkan diri daripada kesukaran hidup. Islam telah menetapkan cara yang tertentu untuk merawat stres, dan ianya telah dinyatakan di dalam al-Quran dan hadis. Kaedah yang dinyatakan itu boleh diaplikasikan dalam masyarakat, sama ada dalam kalangan masyarakat umum atau golongan profesional untuk mengatasi stres.

Pendekatan yang adil dalam usaha merawat pesakit yang menghidapi penyakit psikiatri adalah menerusi rawatan yang bersepadu, iaitu dengan merawat secara ubatan (farmakoterapi), psikoterapi (kejiwaan), pendekatan sosial (kemasyarakatan), dan terapi spiritual (kerohanian). Kefahaman dan pendekatan yang seimbang amat penting dalam memahami penyakit psikiatri dan gangguan jin. Tanpa kefahaman terhadap perkara tersebut akan menyebabkan pesakit terus merana kerana tidak mendapat rawatan yang sempurna. Hanya dengan pengabdian diri kepada Allah SWT secara menyeluruh dan mengikuti sunnah Rasullullah SAW di samping penggunaan kaedah yang rawatan yang diredai oleh Allah SWT, pesakit dapat dibimbing untuk terus menghampirkan diri kepada Allah SW'T dan membebaskan diri daripada belenggu penyakit kejiwaan. ${ }^{17}$

Kebiasaannya individu akan memilih kaedah yang paling sesuai dan dianggap dapat membantu dirinya menghadapi stres. Kaedah ini bersesuaian dengan ajaran agama dan adat resam masyarakat, dan ada juga yang bertentangan dengan ajaran agama, kaedah yang bertentangan di sisi islam tidak mendatangkan feadah terhadap seseorang individu. Sebaliknya ia mugkin hanya meringankan stres yang dihadapi untuk sementara waktu sahaja. Sebagai contoh pengambilan minuman beralcohol, pil penenang, rokok dan mengunjungi pusat hiburan. Kaedah itu semua mungkin memudaratkan terhadap fizikal dan mental manusia, dan ianya menyerupai budaya orang barat.

Islam telah menengahkan beberapa strategi dalam menangani masalah stres, antaranya ialah Istighathah. Bagaimanakah Istighathah mampu merawat jiwa-jiwa manusia yang pada hakikatnya sentiasa berada dalam keadaan stres dan gelisah. Ini dapat disokong dalam kajian yang dijalankan oleh Ainani

\footnotetext{
${ }^{16}$ Danial Zainal Abidin, Perubatan Islam dan Bukti Sains Moden Edisi 2015 (Kuala Lumpur: PTS Millennia, 2015).

${ }^{17}$ Sidi, Menjaga kesihatan jiwa.
} 
Zakiyatul Fuadah 2014 dalam kajiannya yang bertajuk "Peranan Istighathah dalam Mengurangi Kecemasan Siswi Menghadapi Ujian Nasional Di UPTD SMAN I Mojo Kediri" dalam kajiannya membuktikan bahawa dengan mengamalkan Istighathah mampu menjadikan para pelajar menjadi lebih tenang dan tidak mudah putus asa apabila menghadapi kegagalan, malah ianya menambahkan rasa percaya diri terhadap pelajar. ${ }^{18}$ Selain itu juga kesan daripada istighathah mampu menjadikan pelajar lebih bermotivasi untuk menghadapi ujian nasional. Oleh yang demikian istighathah juga boleh diaplikasikan dalam mengatasi masalah stres yang dihadapi dalam kehidupan seseorang individu.

Seperti yang dinyatakan di atas konsep Istightahah ialah memohon pertolongan kepada Allah Swt. bila ditimpa sesuatu musibah, kesukaran, dan kesulitan. Di dalam Istigahthah terdapat pebagai bentuk ibadah termasuklah zikir, doa, selawat, solat, istighfar, dan membaca al-Quran. Amalan tersebut jika di aplikasikan secara berterusan dalam kehidupan seseorang individu maka ianya akan mencapai kepada peringkat taqarrub kepada Allah Swt. Apabila manusia sentiasa dekat dengan Allah Swt, hati dan jiwanya akan berasa tenang. Kebahagian dan kepuasan hati akan tercapai, di samping itu dapat menyingkirkan perasaan gelisah dan resah.

Menurut Ash-Shiddieqy di dalam bukunya Pedoman Zikir dan Doa, menyatakan bahawa Istighathah adalah sebagai media mendekatkan dan menyandarkan diri kepada Allah Swt, orang yang sentiasa berzikir, berdoa, solat dan sebagainya akan sentiasa merasa dekat denganNya dan Allah akan sentiasa bersamanya. Sifat bersama itu adalah sifat yang khusus, kerana ianya bermaksud kebersamaan kerana kedekatan cinta, pertolongan dan taufiq. Aspek ini dilihat sebagai kaedah yang sesuai untuk merawat stres, kerana setiap apa yang berlaku dalam kehidupan manusia adalah dengan kehendak Allah SWT. ${ }^{19}$

Istighathah juga bertujuan menambahkan keimanan, pengabdian dan kematangan cita-cita hidup. Selain itu juga ianya sebagai cara untuk mengendalikan diri, nafsu yang tidak seimbang apabila menghadapi stres. Apabila seseorang melaksanakan Istighathah dengan cara yang ditetapkan dan penuh rasa khusuk maka Allah datangkan beberapa hikmah terhadapnya. Salah satunya ialah seseorang itu akan setiasa sabar, baik dalam keadaan senang dan susah, serta sentiasa bertawakal kepada Allah. Kesabaran dalam menghadapi

\footnotetext{
${ }^{18}$ Fuadah, "Peran Istighasah dalam Mengurangi Kecemasan Siswa Menghadapi Ujian Nasional Di UPTD SMAN I Mojo Kediri."

${ }^{19}$ M. Hasbi Ash Shiddieqy, Pedoman Drikir dan Do'a (Jakarta: Bulan Bintang, 1964).
} 
stres adalah unsur yang penting, kerana ianya menghasilakan kesan positif terhadap orang yang boleh bersabar bila menghadapi stres. Begitu juga sifat tawakal, kerana ianya mendorong individu muslim supaya sentiasa reda dengan ketentuan Allah, seterusnya melepaskan diri daripada sebarang stres pada minda dan jiwa kerana mengetahui dengan penuh keyakinan bahawa manusia hanya mampu berusaha dan merancang, tetapi Allah SWT yang menentukan segalanya. ${ }^{20}$

\section{SIMPULAN}

Dalam kehidupan seharian setiap individu tidak terlepas dari berhadapan dengan stres, yang membezakan adalah dari sudut bentuk dan tahap stres sahaja. Pendekatan Islam harus diaplikasikan dalam menangani stres seperti doa, solat zikir, bertawakal dan muhasabah diri. Di samping itu juga mempertingkatkan dan memperbaiki diri serta bersyukur dengan segala nikmat dan ujian yang Allah SWT hadirkan dalam kehidupan. Selain itu juga dalam proses membina kekuatan jiwa setiap individu muslim mestilah menjadikan kitab suci Al-Quran sebagai panduan dan rujukam utama. Individu yang lalai dalam menjadikan al-Quran sebagai panduan hidup akan menyebabkan jiwa seseorang individu itu menjadi lemah dan mengalami penyakit kejiwaan samada disedari atau tanpa sedar.

\section{Daftar Pustaka}

Abidin, Danial Zainal. Perubatan Islam dan Bukti Sains Moden Edisi 2015. Kuala Lumpur: PTS Millennia, 2015.

Agustin, Wiji Dwi. "Pengaruh Doa Terhadap Coping Stress Pada Santri DiPondok Pesantren Sunan Pandanaran Ngunut." Skripsi, IAIN Tulungagung, 2014. http://repo.iain-tulungagung.ac.id.

Badr, Abdurrazak bin Abdul Muhsin al-. Fiqh Doa Dan Zikir. 1st ed. Pustaka Darul Ilmi, 1999.

Cooper, Cary L., and Judi Marshall. "Occupational Sources of Stress: A Review of the Literature Relating to Coronary Heart Disease and Mental Ill Health." Journal of Occupational Psychology 49, no. 1 (1976): 11-28. https://doi.org/10.1111/j.2044-8325.1976.tb00325.x.

Dafid, Mubaroq. "Pengaruh Istighosah Terhadap Percaya Diri Siswa Menghadapi Ujian Nasional Di Madrasah Tsanawiyah Negeri

${ }^{20}$ Ahmad Syafii Mufid, Zikir Sebagai Pembina Kesejabteraan Jiwa (Surabaya: Bina Ilmu, 1985), 20. 
Karangrejo.” Skripsi, IAIN Tulungagung, 2014. http://repo.iaintulungagung.ac.id/.

Fuadah, Ainani Zakiyatul. "Peran Istighasah dalam Mengurangi Kecemasan Siswa Menghadapi Ujian Nasional Di UPTD SMAN I Mojo Kediri: Kajian Fenomenologis Psikosufistik Pendidikan Islam." Didaktika Religia 2, no. 2 (2014).

Gold, Yvonne, and Robert A. Roth. Teachers Managing Stress \& Preventing Burnout. New York: Routledge, 2013.

Maula, Nikmatul. "Dzikir Istighasah Sebagai Metode Dakwah Pada Jamaah Pengajian Di Pondok Pesantren Al-Fadllu Wal-Fadlilah Kaliwungu Kendal.” Skripsi, UIN Walisongo, 2015. http://eprints.walisongo.ac.id/4800/.

Mubarok, Umi Wakhidatul. "Pengaruh Keaktifan dalam Mengikuti Pengajian Istighosah Malam Senin terhadap Implementasi Sikap Sabar." Skripsi, STAIN Salatiga, 2011.

Mufid, Ahmad Syafii. Zikir Sebagai Pembina Kesejabteraan Jiwa. Surabaya: Bina Ilmu, 1985.

Muhaimin, Khoirul. "Implementasi Terapi Istighatsah dalam Mengatasi Kenakalan Peserta Didik Kelas IX di SMP YPM 3 Beringin Taman Sidoarjo Tahun Pelajaran 2013-2014." Skripsi, UIN Sunan Ampel Surabaya, 2014. http://digilib.uinsby.ac.id/123/.

Najātī, Muḥ ammad 'Uthmān. Jiwa dalam Pandangan Para Filosof Muslim. Bandung: Pustaka Hidayah, 2002.

Shaharom, Mohamed Hatta. Etika Perubatan Islam dan Isu-isu Psikiatri. Kuala Lumpur: Dewan Bahasa dan Pustaka, 2008.

Shiddieqy, M. Hasbi Ash. Pedoman Drikir dan Do'a. Jakarta: Bulan Bintang, 1964.

Sidi, Hatta. Menjaga Kesihatan Jiwa: Teknik Mengurus Stres. Bentong: PTS Publications \& Distributor Sdn. Bhd, 2003.

Taimiyah, Ibn. Istighatsu Fir Raddi 'alal Bakri. 1st ed. Dar al-Riyadh, 1998.

Yuwono, Susatyo. "Mengelola Stres dalam Perspektif Islam dan Psikologi." Psycho Idea 8, no. 2 (July 1, 2010). https://doi.org/10.30595/psychoidea.v8i2.231. 